\title{
DynamicSainT
}

Jilid. IV No. 2., Oktober 2019

\section{EVALUASI KINERJA KAPASITAS SALURAN DRAINASE RAWAN BANJIR KOTA BALIKPAPAN (STUDI KASUS PERUMAHAN GRAHA POLTEKBA)}

\author{
E. H. Pongtuluran ${ }^{1}$, M. Huda ${ }^{2}$ \\ ${ }^{1,2}$ Jurusan Teknik Sipil, Politeknik Negeri Balikpapan, Indonesia. \\ 1ezra.hartarto@poltekba.ac.id, ${ }^{2}$ masrul.huda@poltekba.ac.id
}

\begin{abstract}
ABSTRAK
Perumahan Graha Poltekba Balikpapan merupakan kawasan yang tengah berkembang namun terkadang masih mengalami masalah banjir. Penyebab terjadinya banjir adalah dampak dari perubahan tata guna lahan dan kondisi eksisting dari saluran tersebut, apabila terjadi hujan dengan intensitas besar maka saluran drainase akan meluap memenuhi ruas jalan di beberapa bagian kawasan. Oleh sebab itu, penanganan efektif akibat padatnya pemukiman yang ada yaitu melalui evaluasi kinerja saluran drainase yang ada. Pada penelitian ini diawali survey dimensi dan kondisi drainase pada lokasi penelitian dalam penentuan kapasitas saluran eksisting. Kemudian dilakukan analisis intensitas curah hujan dan kapasitas penggunaan lahan menggunakan bantuan software Arcgis 2.0 dalam menghitung besar debit rencana yang akan masuk dalam saluran drainase. Hasil keduanya lalu dibandingkan, apabila kapasitas saluran lebih besar daripada debit rencana maka dapat dikatakan saluran tersebut masih dapat bekerja secara efektif, namun apabila sebaliknya maka perlu dilakukan perubahan dimensi pada saluran tersebut. Hasil penelitian menunjukkan terdapat dua saluran yang memiliki kapasitas yang kurang terhadap debit rencana yang akan masuk pada saluran, yakni pada saluran P3 dimana kapasitas hanya dapat menampung debit aliran sebesar $0,982 \mathrm{~m}^{3} / \mathrm{s}$ sedangkan debit rencana aliran adalah $1,160 \mathrm{~m}^{3} / \mathrm{s}$ dan pada saluran S8 dengan kapasitas $0,176 \mathrm{~m}^{3} / \mathrm{s}$ sedangkan debit rencana $0,778 \mathrm{~m}^{3} / \mathrm{s}$ sehingga perlu dilakukan koreksi dimensi pada saluran tersebut. Dalam analisis perubahan dimensi didapatkan ketinggian pada saluran P3 adalah 1,181 meter dari yang awalnya hanya 1,00 meter dan ketinggian pada saluran S8 adalah 1,765 meter dari tinggi awal hanya 0,40 meter.
\end{abstract}

Kata Kunci: tata guna lahan, kapasitas drainase, sedimentasi.

\section{PENDAHULUAN}

Pertumbuhan kota dan perkembangan sektor lainnya menimbulkan dampak yang cukup besar terhadap jaringan drainase, diantaranya dari sektor penggunaan lahan yang kurang adanya penanganan dari pihak terkait. Dampak dari perubahan tata guna lahan yaitu pada drainase perkotaan, apabila terjadi hujan dengan intensitas besar saluran drainase akan meluap memenuhi ruas jalan. Hal ini menunjukkan bahwa sistem drainase diperkotaan yang mengalami bencana banjir tersebut masih belum menunjukkan kinerja maksimal atau bahkan tidak terencana dengan baik termasuk pada perumahan Graha Poltekba Balikpapan.
Keterbatasan dalam sistem drainase ini mengakibatkan ketidaknyamanan masyarakat. Untuk itu perlu adanya evaluasi kinerja terhadap saluran drainase yang telah ada khususnya kawasan rawan banjir Dengan meninjau uraian di atas dan permasalaahan yang terjadi maka tujuan dari penelitian ini adalah:

1. Mengkaji kondisi dimensi saluran drainase Perumahan Graha Poltekba Kota Balikpapan,

2. Menganalisis kinerja saluran drainase yang telah ada, 3. Mengevaluasi dampak penanganan banjir terhadaap sistem saluran drainase yang digunakan.

Hasil penelitian ini diharapkan dapat bermanfaat untuk:

1. mendapatkan desain rencana optimum 


\section{DynamicSainT}

Jilid. IV No. 2., Oktober 2019

terhadap saluran drainase pada kawasan rawan banjir,

2. memberikan alternatif cara penanggulangan efektif terhadap kapasitas saluran drainase rawan banjir,

3. memberikan evaluasi untuk bahan pertimbangan bagi pengambil kebijakan dalam pengelolaan jaringan saluran berkelanjutan terkait dengan kinerja sistem drainase.

\section{KAJIAN PUSTAKA}

\subsection{Sistem Drainase Perkotaan}

Sistem drainase dapat didefinisikan sebagai serangkaian bangunan air yang berfungsi untuk mengurangi dan membuang kelebihan air dari suatu kawasan atau lahan, sehingga lahan dapat difungsikan secara optimal (Suripin, 2004).

Sistem jaringan drainase perkotaan umumnya terdiri dari sistem drainase mayor yaitu sistem saluran atau badan air yang menampung dan mengalirkan air dari suatu daerah tangkapan air hujan (Catchment Area) dimana jaringan ini menampung aliran berskala besar dan luas seperti saluran drainase primer dengan masa perencanaan dengan kala ulang antara 5 sampai 10 tahun, sedangkan sistem drainase mikro yaitu sistem saluran dan bangunan pelengkap drainase yang menampung dan mengalirkan air dari daerah tangkapan hujan seperti saluran drainase maupun gorong-gorong.

\subsection{Faktor Penyebab Banjir Perkotaan}

Banjir atau genangan di suatu kawasan terjadi apabila sistem yang berfungsi untuk menampung genangan itu tidak mampu menampung debit yang mengalir, hal ini akibat dari tiga kemungkinan yang terjadi yaitu: kapasitas sistem yang menurun, debit aliran air yang meningkat, atau kombinasi dari keduaduanya. Pengertian sistem disini adalah sistem jaringan drainase di suatu kawasan, sedangkan sistem drainase secara umum dapat didefinisikan sebagai serangkaian bangunan air yang berfungsi untuk mengurangi dan/atau membuang kelebihan air (banjir) dari suatu kawasan atau lahan, sehingga lahan dapat difungsikan secara optimal, jadi sistem drainase adalah rekayasa infrastruktur di suatu kawasan untuk menanggulangi adanya genangan banjir (Suripin, 2004)

\subsection{Evaluasi Kinerja Drainase}

Keberhasilan suatu sistem drainase dalam mencapai tujuan yang direncanakan dapat dilihat dari kinerja sistem drainase itu sendiri. Indikator yang mempengaruhi kinerja sistem drainase sebagai berikut ini:

- Indikator bangunan drainase dan pelengkapnya

Berfungsinya bangunan drainase dan pelengkap sesuai dengan

kegunaannya maka sangat mempengaruhi kinerja sistem drainase dilihat dari kelancaran air dalam saluran drainase baik saluran tertutup maupun terbuka.

Indikator banjir

Masih ditemukannnya banjir pada suatu kawasan, maka kinerja sistem jaringan drainase daerah tersebut dapat dikatakan tidak baik, dilihat dari sebaran genangan, luas genangan, lama genangan dan tinggi genangan

\subsection{Faktor Penyebab Banjir Perkotaan}

Menghitung debit limpasan yang masuk sebagai fungsi karakteristik luas lahan dapat menggunakan metode rasional. Pemakaian metode rasional sangat sederhana dan sering digunakan dalam perencanaan drainase perkotaan. Metode rasional didasarkan persamaan 1 .

$Q=0.278 C I$

dimana:

$Q=$ debit banjir maksimum $\left(\mathrm{m}^{3} / \mathrm{s}\right)$,

$C=$ koefisien limpasan, 


\section{DynamicSainT}

Jilid. IV No. 2., Oktober 2019

$I=$ intensitas hujan ( $\mathrm{mm} / \mathrm{jam})$,

$A=$ luas daerah tangkapan $\left(\mathrm{km}^{2}\right)$.

Untuk koefisien limpasan ditentukan berdasarkan penggunaan lahan pada kawasan yang bersangkutan. Jika DAS terdiri dari berbagai macam penggunaan lahan dengan koefisien limpasan yang berbeda, maka $\mathrm{C}$ yang dipakai adalah koefisien DAS yang dapat dihitung menggunakan persamaan 3 .



dimana:

$$
\begin{aligned}
A_{i}= & \text { luas lahan dengan jenis } \\
& \text { penggunaan lahan } \mathrm{i}\left(\mathrm{km}^{2}\right), \\
C_{i}= & \text { koefisien limpasan permukaan } \\
& \text { dengan jenis penggunaan lahan } \mathrm{i}, \\
I= & \text { jumlah jenis penggunaan lahan. }
\end{aligned}
$$

\subsection{Kapasistas Saluran Drainase}

Kapasitas saluran drainase merupakan kemampuan untuk melewatkan sejumlah debit tertentu yang melalui saluran tersebut. Kapasitas saluran dipengaruhi oleh dua faktor yaitu luas penampang dan kecepatan aliran. Kecepatan aliran ditentukan oleh kemiringan saluran, radius hidraulik (hasil bagi antara luas penampang dengan perimeter saluran) dan koefisien kekasaran saluran tersebut. Kapasitas setiap penampang dihitung berdasarkan rumus berikut ini.

$$
\begin{aligned}
& Q_{c}=V A \\
& V=\frac{1}{\square} \square^{2 / 3} \square^{1 / 2} \\
& R=\frac{\square}{\square}
\end{aligned}
$$

dimana:

$\mathrm{V}=$ kecepatan aliran rata-rata $(\mathrm{m} / \mathrm{s})$,

$\mathrm{n} \quad=$ koefisien kekasaran saluran,

A = luas penampang basah $\left(\mathrm{m}_{2}\right)$,

$Q_{\mathrm{c}} \quad=$ debit aliran $\left(\mathrm{m}^{3} / \mathrm{s}\right)$,

$\mathrm{R} \quad=$ jari-jari hidrolik $(\mathrm{m})$,
$\mathrm{S}=$ kemiringan permukaan aliran,

$\mathrm{P} \quad=$ keliling basah saluran $(\mathrm{m})$

Kondisi setiap saluran dan sekitar saluran juga berbeda-beda sehingga berpengaruh pada koefisien kekasaran suatu saluran. Penentuan kekasaran ekivalen $\mathrm{n}$ (kekasaran untuk keseluruhan keliling basah penampang saluran), bahwa setiap bagian dari luas memiliki nilai kecepatan rata-rata yang sama untuk penampang keseluruhan, yaitu V1 = V2 ... = VN = V (Horton, 1933). Dengan demikian koefisien kekasaran ekivalen diperoleh dari persamaan 7.

$$
n=\frac{\left(\square \square_{1}^{1,5}+\square \square^{1,5}+\cdots+\square \square^{1,5}\right)^{2 / 3}}{(\square \text { a } \square \square \square)^{2 / 3}}
$$

Nilai keliling basah saluran (P) yang digunakan tergantung dari dimensi saluran drainase sedangkan nilai kekasaran saluran (n) yang digunakan berdasarkan tabel nilai kekasaran yang dilakukan dari berbagai penelitian.

\section{TAHAPAN PENELITIAN}

Tahapan penelitian dilakukan melalui beberapa tahap yang dapat digambarkan dalam bagan alir penelitian pada Gambar 1 .

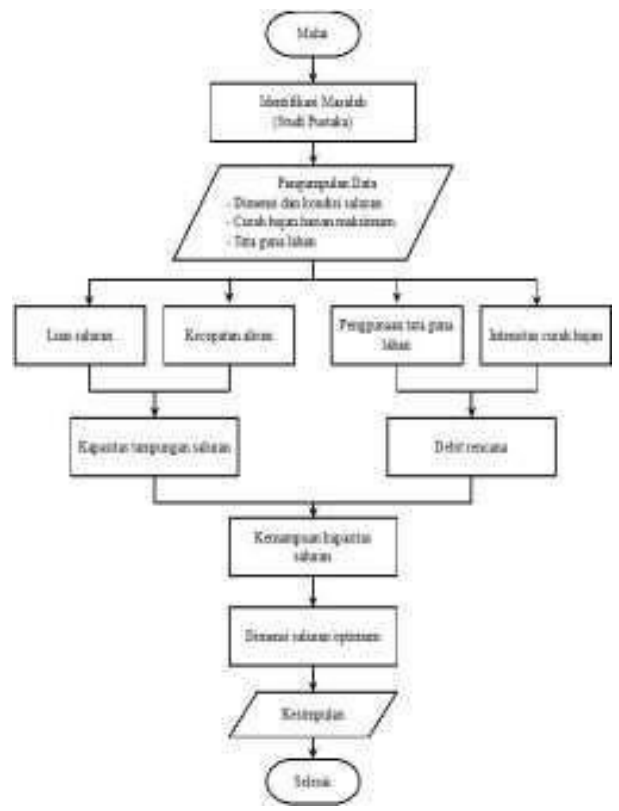

Gambar 1. Bagan Alir Penelitian 


\section{DynamicSainT}

Jilid. IV No. 2., Oktober 2019

\section{HASIL DAN PEMBAHASAN}

\subsection{Analisis Frekuensi Hujan Harian Maksimum}

Perhitungan hujan rancangan dapat dilakukan dengan beberapa metode distribusi frekuensi hujan (lihat Tabel 1). Menurut uji Chi Square dan Smirnov Kolmogorov yang terbaik menggunakan distribusi Log-Pearson III karena nilai selisih peluang lapangan dengan peluang teroritis lebih kecil daripada nilai kritisnya.
Tabel 1 : Rekapitulasi hasil perhitungan hujan rancangan

\begin{tabular}{|c|c|c|c|c|c|}
\hline \multirow{2}{*}{ No } & \multirow{2}{*}{$\begin{array}{c}\text { Kala } \\
\text { Ulang }\end{array}$} & \multicolumn{4}{|c|}{ Distribusi Curah Hujan Rencana (mm/hari) } \\
\cline { 3 - 6 } & Tahun) & Normal & $\begin{array}{c}\text { Log } \\
\text { Normal }\end{array}$ & $\begin{array}{c}\text { Gumbe } \\
\text { I }\end{array}$ & $\begin{array}{c}\text { Log } \\
\text { Pearson III }\end{array}$ \\
\hline 1 & 2 & 125,610 & 121,180 & 120,73 & 120,6097 \\
2 & 5 & 155,845 & 153,559 & 163,69 & 153,3824 \\
3 & 10 & 171,682 & 173,839 & 192,13 & 174,4097 \\
4 & 25 & 184,640 & 192,408 & 219,41 & 200,4338 \\
5 & 50 & 199,398 & 215,984 & 254,73 & 219,4044 \\
6 & 100 & 209,476 & 233,724 & 281,19 & 238,3816 \\
\hline
\end{tabular}

\subsection{Intensitas Curah Hujan Rancangan}

Perhitungan intensitas curah hujan kala ulang rancangan menggunakan metode Mononobe dapat dilihat Tabel 2dan Kurva IDF hasil perhitungan Tabel disajikan dalam gambar 2 .

Tabel 2. Perhitungan intensitas curah hujan rancangan metode Mononobe

\begin{tabular}{|c|c|c|c|c|c|c|c|c|c|c|c|c|c|}
\hline $\mathrm{T}$ & $\sqcap_{24}^{\square}$ & & & & & ensitas & $\operatorname{lan}\left(\square^{D} / j a\right.$ & pada me & nit ke & & & & \\
\hline (tahun) & $(\mathrm{mm})$ & 5 & 10 & 15 & 20 & 25 & 30 & 45 & 60 & 90 & 120 & 150 & 180 \\
\hline 2 & 120,61 & 219,16 & 138,06 & 105,36 & 86,97 & 74,95 & 66,37 & 50,65 & 41,81 & 31,91 & 26,34 & 22,70 & 20,10 \\
\hline 25 & 200,43 & 364,21 & 229,44 & 175,10 & 144,54 & 124,56 & 110,30 & 84,18 & 69,49 & 53,03 & 43,77 & 37,72 & 33,41 \\
\hline 50 & 219,40 & 398,68 & 251,16 & 191,67 & 158,22 & 136,35 & 120,74 & 92,14 & 76,06 & 58,05 & 47,92 & 41,29 & 36,57 \\
\hline 100 & 238,38 & 433,17 & 272,88 & 208,25 & 171,90 & 148,14 & 131,19 & 100,11 & 82,64 & 63,07 & 52,06 & 44,87 & 39,73 \\
\hline
\end{tabular}



Gambar 2. Kurva IDF metode Mononobe pada lokasi penelitian 


\section{DynamicSainT}

Jilid. IV No. 2., Oktober 2019

\subsection{Kondisi Eksisting Saluran}

Pengamatan kondisi saluran yang ada saat ini (eksisting) perlu dilakukan untuk mengetahui hal-hal yang dapat mempengaruhi kinerja saluran tersebut. Gambar 3 menunjukkan arah aliran yang terjadi pada lokasi. Langkah awal dalam analisis penentuan kapasitas sebuah saluran dengan melihat kondisi langsung dilapangan kemudian dilakukan pengukuran berdasarkan kondisi asli yang telah dibuat

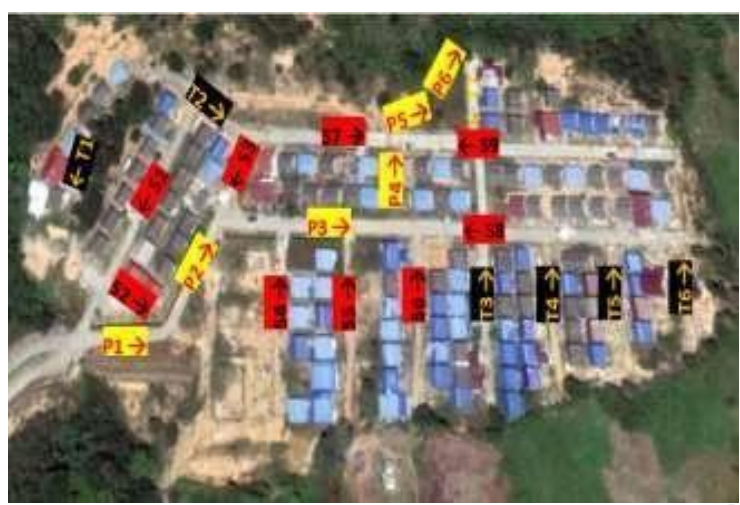

Gambar 3. Pembagian arah aliran pada saluran.

Berdasarikan pembagian arah jenis aliran diatas, maka dilakukan pengukuran dimensi saluran eksisting dan didapatkan hasil rekapitulasi pengkuran dimensi saluran seperti yang dapat dilihat pada Tabel 3 .
Tabel 3. Dimensi Saluran Eksisting

\begin{tabular}{|c|c|c|c|c|c|}
\hline Uraian & Panjang & Lebar & $\begin{array}{c}\text { Kedala } \\
\text { man }\end{array}$ & $\begin{array}{c}\text { Keliling } \\
\text { Saluran }\end{array}$ & $\begin{array}{c}\text { Luas } \\
\text { Saluran }\end{array}$ \\
\cline { 2 - 6 } & $\mathbf{L}$ & $\mathbf{b}$ & $\mathbf{h}$ & $\mathbf{P}$ & $\mathbf{A}$ \\
\cline { 2 - 6 } & $\mathbf{( m )}$ & $\mathbf{( m )}$ & $\mathbf{( m )}$ & $\mathbf{( m )}$ & $\mathbf{( \mathbf { m } ^ { 2 } )}$ \\
\hline Saluran P1 & 34,45 & 1,40 & 1,10 & 3,60 & 1,54 \\
Saluran P2 & 29,50 & 1,55 & 1,10 & 3,75 & 1,71 \\
Saluran P3 & 76,00 & 1,05 & 1,00 & 3,05 & 1,05 \\
\hline Saluran P4 & 27,50 & 1,00 & 1,20 & 3,40 & 1,20 \\
Saluran P5 & 10,40 & 2,00 & 1,00 & 4,00 & 2,00 \\
Saluran P6 & 11,00 & 2,00 & 1,00 & 4,00 & 2,00 \\
Saluran S1 & 60,00 & 0,45 & 0,40 & 1,25 & 0,18 \\
Saluran S2 & 72,60 & 0,45 & 0,55 & 1,55 & 0,25 \\
Saluran S3 & 26,15 & 0,30 & 0,25 & 0,80 & 0,08 \\
Saluran S4 & 59,00 & 0,55 & 0,45 & 1,45 & 0,25 \\
Saluran S5 & 60,00 & 0,55 & 0,45 & 1,45 & 0,25 \\
Saluran S6 & 61,65 & 0,55 & 0,48 & 1,51 & 0,26 \\
Saluran S7 & 62,00 & 0,60 & 0,56 & 1,72 & 0,34 \\
Saluran S8 & 140,00 & 0,40 & 0,40 & 1,20 & 0,16 \\
Saluran S9 & 139,50 & 0,40 & 0,40 & 1,20 & 0,16 \\
Saluran T1 & 95,00 & 0,35 & 0,40 & 1,15 & 0,14 \\
Saluran T2 & 40,00 & 0,50 & 0,50 & 1,50 & 0,25 \\
Saluran T3 & 57,50 & 0,40 & 0,45 & 1,30 & 0,18 \\
Saluran T4 & 72,00 & 0,45 & 0,45 & 1,35 & 0,20 \\
Saluran T5 & 42,50 & 0,45 & 0,40 & 1,25 & 0,18 \\
Saluran T6 & 35,50 & 0,45 & 0,45 & 1,35 & 0,20 \\
Saluran T7 & 30,00 & 0,45 & 0,45 & 1,35 & 0,20 \\
\hline
\end{tabular}

\subsection{Kapasitas Saluran}

Besarnya suatu kapasitas saluran pada lokasi penelitian dapat dilihat dari Tabel 4 . Saluran yang memiliki kapasitas terbesar dibandingkan saluran yang lain adalah terdapat pada saluran P5 dan P6 yaitu sebesar $7,49 \mathrm{~m}^{3} / \mathrm{s}$ dan $9,08 \mathrm{~m}^{3} / \mathrm{s}$.

Tabel 4. Kapasitas tampungan saluran

\begin{tabular}{|c|c|c|c|c|c|c|c|c|}
\hline \multirow[t]{2}{*}{ No } & \multirow[t]{2}{*}{ Uraian } & $\begin{array}{l}\text { Keliling } \\
\text { Saluran }\end{array}$ & $\begin{array}{c}\text { Luas } \\
\text { Saluran }\end{array}$ & $\begin{array}{l}\text { Jari-jari } \\
\text { Hidrolis }\end{array}$ & \multirow[t]{2}{*}{$\begin{array}{c}\text { Kekasaran } \\
\text { Saluran }\end{array}$} & \multirow[t]{2}{*}{$\begin{array}{c}\text { Kemiringan } \\
\text { Saluran }\end{array}$} & $\begin{array}{c}\text { Kecepatan } \\
\text { Aliran }\end{array}$ & $\begin{array}{c}\text { Kapasitas } \\
\text { Saluran }\end{array}$ \\
\hline & & (m) & $\left(\mathrm{m}^{2}\right)$ & (m) & & & $(\mathrm{m} / \mathrm{s})$ & $\left(\mathrm{m}^{3} / \mathrm{s}\right)$ \\
\hline 1 & Saluran P1 & 3,60 & 1,54 & 0,428 & 0,033 & 0,0087 & 1,61 & 2,47 \\
\hline 2 & Saluran P2 & 3,75 & 1,71 & 0,455 & 0,033 & 0,0102 & 1,81 & 3,08 \\
\hline 3 & Saluran P3 & 3,05 & 1,05 & 0,344 & 0,033 & 0,0039 & 0,94 & 0,98 \\
\hline 4 & Saluran P4 & 3,40 & 1,20 & 0,353 & 0,033 & 0,0109 & 1,58 & 1,90 \\
\hline 5 & Saluran P5 & 4,00 & 2,00 & 0,500 & 0,033 & 0,0385 & 3,74 & 7,49 \\
\hline 6 & Saluran P6 & 4,00 & 2,00 & 0,500 & 0,026 & 0,0364 & 4,54 & 9,08 \\
\hline 7 & Saluran S1 & 1,25 & 0,18 & 0,144 & 0,019 & 0,0283 & 2,43 & 0,44 \\
\hline 8 & Saluran S2 & 1,55 & 0,25 & 0,160 & 0,019 & 0,0262 & 2,51 & 0,62 \\
\hline 9 & Saluran S3 & 0,80 & 0,08 & 0,094 & 0,019 & 0,0191 & 1,50 & 0,11 \\
\hline 10 & Saluran S4 & 1,45 & 0,25 & 0,171 & 0,019 & 0,0220 & 2,40 & 0,59 \\
\hline 11 & Saluran S5 & 1,45 & 0,25 & 0,171 & 0,019 & 0,0367 & 3,10 & 0,77 \\
\hline 12 & Saluran S6 & 1,51 & 0,26 & 0,175 & 0,019 & 0,0357 & 3,11 & 0,82 \\
\hline 13 & Saluran S7 & 1,72 & 0,34 & 0,195 & 0,019 & 0,0242 & 2,76 & 0,93 \\
\hline 14 & Saluran S8 & 1,20 & 0,16 & 0,133 & 0,019 & 0,0064 & 1,10 & 0,18 \\
\hline 15 & Saluran S9 & 1,20 & 0,16 & 0,133 & 0,019 & 0,0043 & 0,90 & 0,14 \\
\hline 16 & Saluran T1 & 1,15 & 0,14 & 0,122 & 0,017 & 0,0316 & 2,58 & 0,36 \\
\hline 17 & Saluran T2 & 1,50 & 0,25 & 0,167 & 0,017 & 0,0750 & 4,87 & 1,22 \\
\hline 18 & Saluran T3 & 1,30 & 0,18 & 0,138 & 0,017 & 0,0487 & 3,48 & 0,63 \\
\hline
\end{tabular}




\section{DynamicSainT}

Jilid. IV No. 2., Oktober 2019

\begin{tabular}{|c|c|c|c|c|c|c|c|c|}
\hline \multirow{2}{*}{ No } & \multirow{2}{*}{ Uraian } & $\begin{array}{c}\text { Keliling } \\
\text { Saluran }\end{array}$ & $\begin{array}{c}\text { Luas } \\
\text { Saluran }\end{array}$ & $\begin{array}{c}\text { Jari-jari } \\
\text { Hidrolis }\end{array}$ & \multirow{2}{*}{$\begin{array}{c}\text { Kekasaran } \\
\text { Saluran }\end{array}$} & $\begin{array}{c}\text { Kemiringan } \\
\text { Saluran }\end{array}$ & $\begin{array}{c}\text { Kecepatan } \\
\text { Aliran }\end{array}$ & $\begin{array}{c}\text { Kapasitas } \\
\text { Saluran }\end{array}$ \\
& & $(\mathrm{m})$ & $\left(\mathrm{m}^{2}\right)$ & $(\mathrm{m})$ & & & $(\mathrm{m} / \mathrm{s})$ & $(\mathrm{m} / \mathrm{s})$ \\
\hline 19 & Saluran T4 & 1,35 & 0,20 & 0,150 & 0,017 & 0,0389 & 3,27 & 0,66 \\
20 & Saluran T5 & 1,25 & 0,18 & 0,144 & 0,017 & 0,0682 & 4,19 & 0,75 \\
21 & Saluran T6 & 1,35 & 0,20 & 0,150 & 0,017 & 0,0761 & 4,57 & 0,93 \\
22 & Saluran T7 & 1,35 & 0,20 & 0,150 & 0,017 & 0,0100 & 1,66 & 0,34 \\
\hline
\end{tabular}

\subsection{Perencanaan Dimensi Saluran Optimum}

Pada tahapan ini dilakukan analisis besar debit aliran yang terjadi sehingga dapat mengetahui kapasitas dari saluran yang telah ada, kemudian melakukan evaluasi perubahan dimensi apabila kemampuan saluran sudah tidak mampu menampung aliran yang terjadi.

\subsubsection{Peta Penggunaan}

Lahan Penggunaan suatu lahan pada kawasan mempengaruhi besarnya debit

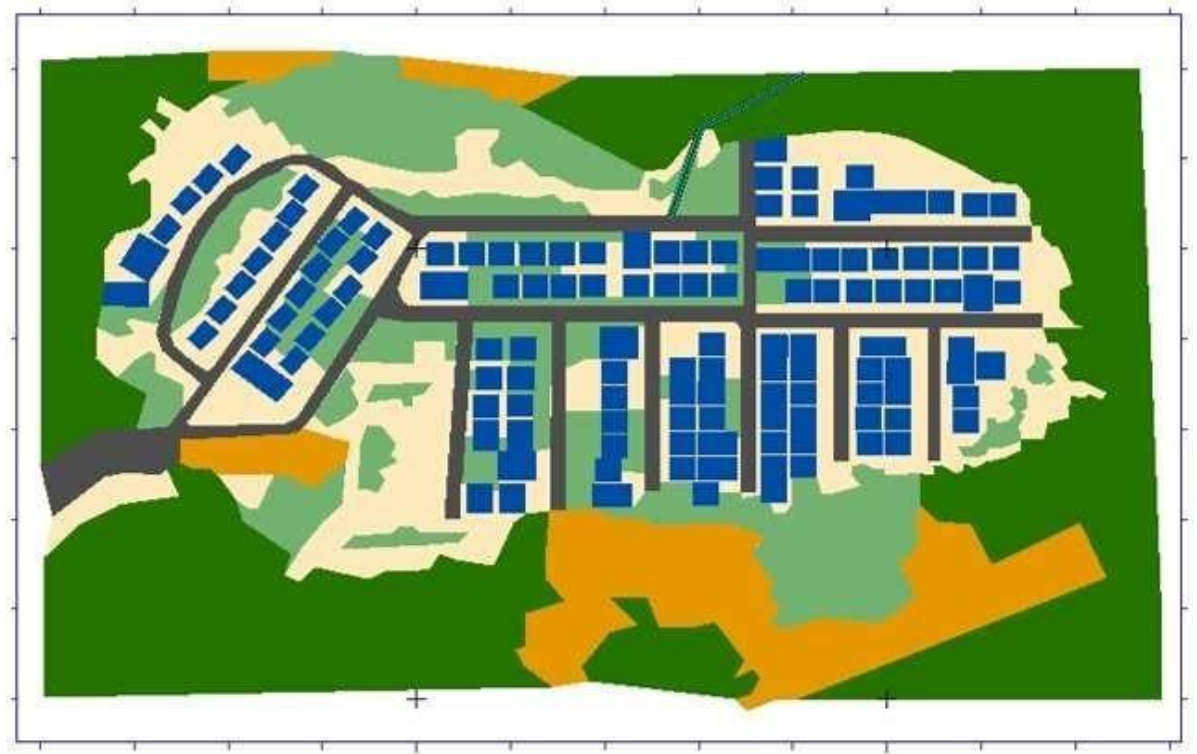

rencana yang akan terjadi. Semakin besar penggunaan lahan oleh bangunan perkerasan, maka semakin besar pula debit yang akan masuk dalam saluran. Hal ini dikarenakan, aliran yang harusnya masuk kedalam tanah, kini lahannya telah berubah menjadi bangunan. Adapun bentuk penggunaan lahan yang terjadi pada lokasi dapat dilihat pada Gambar 4.

\section{Legend}

Gambar 10. Peta penggunaan lahan lokasi peneliti



\subsubsection{Debit Rencana Saluran}

Debit rencana merupakan volume aliran yang akan masuk pada saluran dimana tergantung dari faktor tingginya intensitas hujan dan penggunaan pada suatu lahan. Debit rencana pada lokasi penelitan dapat dilihat pada Tabel 5.
Tabel 5. Debit rencana saluran

\begin{tabular}{|c|c|c|c|c|c|}
\hline \multirow{2}{*}{ No } & Uraian & $\begin{array}{c}\text { Koefisien } \\
\text { Lahan }\end{array}$ & $\begin{array}{c}\text { Intensitas } \\
\text { Hujan }\end{array}$ & Luas Lahan & $\begin{array}{c}\text { Debit } \\
\text { Rencana }\end{array}$ \\
& & & & & \\
\cline { 3 - 6 } & & $\mathrm{C}$ & $\mathrm{I}$ & $\mathrm{A}$ & $\mathrm{Qr}$ \\
\hline 1 & Saluran P1 & 0,25 & 471,17 & 0,0073 & 0,2341 \\
2 & Saluran P2 & 0,38 & 531,69 & 0,0040 & 0,2253 \\
3 & Saluran P3 & 0,45 & 344,09 & 0,0025 & 0,1073 \\
4 & Saluran P4 & 0,45 & 631,55 & 0,0004 & 0,0330 \\
5 & Saluran P5 & 0,27 & 495,06 & 0,0007 & 0,0267 \\
6 & Saluran P6 & 0,17 & 481,95 & 0,0036 & 0,0832
\end{tabular}




\section{DynamicSainT}

Jilid. IV No. 2., Oktober 2019

\begin{tabular}{|c|c|c|c|l|l|}
7 & Saluran S1 & 0,53 & 498,81 & 0,0016 & 0,1156 \\
8 & Saluran S2 & 0,72 & 781,74 & 0,0009 & 0,1448 \\
9 & Saluran S3 & 0,55 & 505,86 & 0,0005 & 0,0358 \\
10 & Saluran S4 & 0,30 & 421,53 & 0,0040 & 0,1392 \\
11 & Saluran S5 & 0,35 & 558,41 & 0,0049 & 0,2661 \\
12 & Saluran S6 & 0,44 & 566,70 & 0,0035 & 0,2428 \\
13 & Saluran S7 & 0,36 & 414,79 & 0,0060 & 0,2497 \\
14 & Saluran S8 & 0,68 & 264,30 & 0,0021 & 0,1038 \\
15 & Saluran S9 & 0,64 & 214,80 & 0,0020 & 0,0765 \\
16 & Saluran T1 & 0,30 & 390,99 & 0,0059 & 0,1935 \\
17 & Saluran T2 & 0,36 & 600,04 & 0,0023 & 0,1348 \\
18 & Saluran T3 & 0,46 & 616,71 & 0,0023 & 0,1864 \\
19 & Saluran T4 & 0,48 & 549,09 & 0,0024 & 0,1727 \\
20 & Saluran T5 & 0,38 & 692,16 & 0,0024 & 0,1756 \\
21 & Saluran T6 & 0,24 & 651,56 & 0,0031 & 0,1391 \\
22 & Saluran T7 & 0,31 & 349,71 & 0,0013 & 0,0411 \\
\hline
\end{tabular}

Berdasarkan tabel diatas, maka dapat dilakukan perhitungan komulatif debit rencana yang terjadi pada saluran seperti pada Gambar 5.

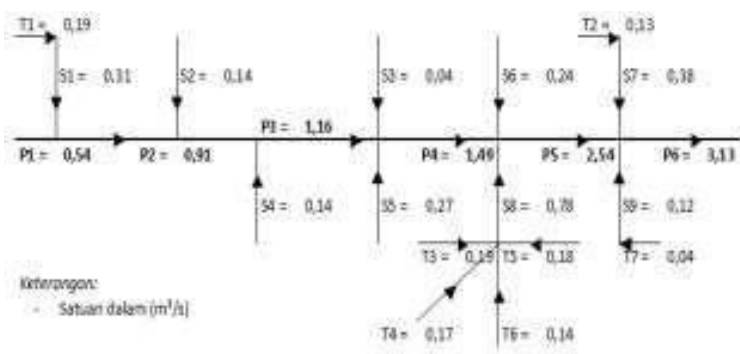

Gambar 5. Komulatif debit aliran pada saluran

\subsubsection{Kemampuan Kapasitas Saluran}

Kemampuan kapasitas saluran dapat dilakukan dengan membandingkan kapasitas suatu saluran terhadap debit aliran rencana yang akan masuk pada saluran. Nilai kemampuan suatu kapasitas saluran dapat dilihat pada Tabel 6 .

Tabel 6. Kemapuan Kapasitas Saluran

\begin{tabular}{|r|c|c|c|c|}
\hline No. & Uraian & $\begin{array}{c}\text { Debit } \\
\text { Saluran } \\
\left(\mathrm{m}^{3} / \mathrm{s}\right)\end{array}$ & $\begin{array}{c}\text { Debit } \\
\text { Rencana } \\
\left(\mathrm{m}^{3} / \mathrm{s}\right)\end{array}$ & Keterangan \\
\hline 1 & Saluran P1 & 2,472 & 0,543 & OK \\
2 & Saluran P2 & 3,081 & 0,913 & OK \\
3 & Saluran P3 & 0,982 & 1,160 & KOREKSI \\
4 & Saluran P4 & 1,897 & 1,495 & OK \\
5 & Saluran P5 & 7,488 & 2,542 & OK \\
6 & Saluran P6 & 9,076 & 3,127 & OK \\
7 & Saluran S1 & 0,438 & 0,309 & OK \\
8 & Saluran S2 & 0,620 & 0,145 & OK \\
9 & Saluran S3 & 0,113 & 0,036 & OK \\
10 & Saluran S4 & 0,595 & 0,139 & OK
\end{tabular}

\begin{tabular}{|c|c|c|c|c|}
\hline No. & Uraian & $\begin{array}{c}\text { Debit } \\
\text { Saluran } \\
\left(\mathrm{m}^{3} / \mathrm{s}\right)\end{array}$ & $\begin{array}{c}\text { Debit } \\
\text { Rencana } \\
\left(\mathrm{m}^{3} / \mathrm{s}\right)\end{array}$ & Keterangan \\
\hline 11 & Saluran S5 & 0,768 & 0,266 & OK \\
12 & Saluran S6 & 0,821 & 0,243 & OK \\
13 & Saluran S7 & 0,926 & 0,384 & OK \\
14 & Saluran S8 & 0,176 & 0,778 & KOREKSI \\
15 & Saluran S9 & 0,144 & 0,118 & OK \\
16 & Saluran T1 & 0,361 & 0,193 & OK \\
17 & Saluran T2 & 1,218 & 0,135 & OK \\
18 & Saluran T3 & 0,627 & 0,186 & OK \\
19 & Saluran T4 & 0,662 & 0,173 & OK \\
20 & Saluran T5 & 0,755 & 0,176 & OK \\
21 & Saluran T6 & 0,926 & 0,139 & OK \\
22 & Saluran T7 & 0,336 & 0,041 & OK \\
\hline
\end{tabular}

Pada tabel 6 terdapat dua saluran yang memiliki kapasitas yang kurang terhadap debit rencana yang akan masuk pada saluran, yakni pada saluran P3 dan S8 sehingga perlu dilakukan koreksi dimensi pada saluran.

\subsubsection{Dimensi Saluran Optimum}

Terdapat dua saluran yang masih kurang efektif dalam menampung debit aliran rencana sehingga perlu dilakukan perubahan dimensi pada saluran. Hasil perhitungan perubahan dimensi tinggi saluran dapat dilihat pada Tabel 7.

Tabel 7. Dimensi saluran optimum

\begin{tabular}{|c|c|c|c|c|c|}
\hline Uraian & $\begin{array}{l}\text { Debit } \\
\text { Rencana } \\
\left(\mathrm{m}^{3} / \mathrm{s}\right)\end{array}$ & $\begin{array}{c}\text { Kecepatan } \\
\text { Aliran } \\
(\mathrm{m} / \mathrm{s})\end{array}$ & $\begin{array}{c}\text { Luas } \\
\text { Rencana } \\
\left(\mathrm{m}^{2}\right)\end{array}$ & $\begin{array}{c}\text { Lebar } \\
\text { Eksisting } \\
(\mathrm{m})\end{array}$ & $\begin{array}{c}\text { Tinggi } \\
\text { Rencana } \\
(\mathrm{m})\end{array}$ \\
\hline Saluran P3 & 1,16 & 0,94 & 1,240 & 1,05 & 1,181 \\
Saluran S8 & 0,778 & 1,10 & 0,706 & 0,40 & 1,765 \\
\hline
\end{tabular}

Hasil perhitungan perubahan dimensi didapatkan tinggi optimum dalam menampung debit rencana aliran pada saluran P3 adalah 1,181 meter dari tinggi awal saluran 1,00 meter dan pada saluran S8 adalah 1,765 meter dari tinggi awal saluran 0,40 meter.

\subsection{Alternatif Konstruksi Terhadap Kapasitas Saluran \\ Berdasarkan pengamatan dilapangan,} terdapat beberapa masalah yang terjadi pada kondisi saluran eksisting sehingga mengakibatkan berkurangnya kapasitas saluran. Masalah utama yang biasa terjadi pada saluran adalah sedimentasi, sehingga 


\section{DynamicSainT}

Jilid. IV No. 2., Oktober 2019

perlu dilakukam sistem kontrol terhadap sedimentasi tersebut. Alternatif yang dapat dilakukan dalam mengontrol sedimentasi pada saluran adalah membuat suatu konstruksi yang dapat menjebak sedimen agar mudah dikontrol sehingga tidak menyebar sepanjang saluran yang ada, yaitu dengan membuat kolam sedimentasi/bak kontrol. Bentuk konstruksi yang disarankan mengikuti dari bentuk saluran yang telah ada, namum memiliki kedalaman yang berbeda sehingga memudahkan dalam mengkontrol sedimentasi yang terjadi pada saluran. Adapun lokasi yang memerlukan perhatian khusus dikarenakan memiliki sedimentasi cukup tinggi sesuai dengan pengamatan dilapangan dapat dilihat pada Gambar 6

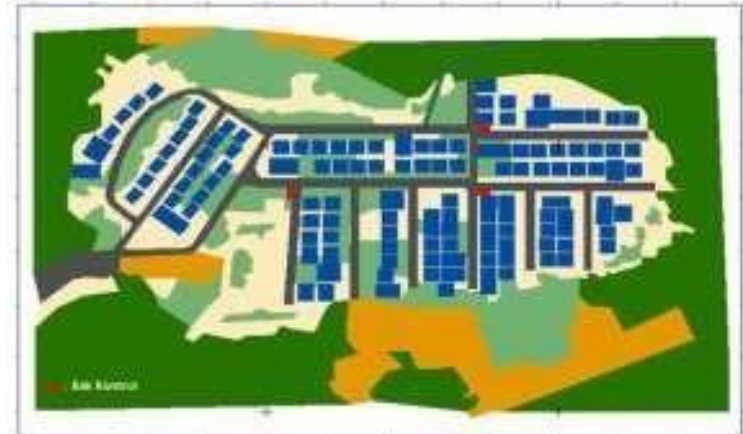

Gambar 6. Lokasi penempatan bak kontrol

Efektivitas kedalaman bak kontrol tergantung dari letak dan tinggi eksisting saluran. Adapun bentuk bak kontrol dapat dilihat pada Gambar 7.

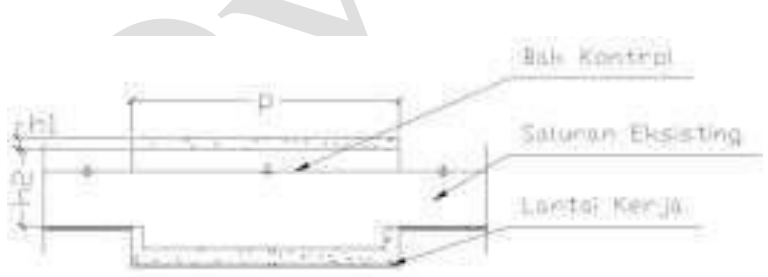

(a) Potongan memanjang bak kontrol



(b) Potongan melintang bak kontrol

Gambar 7. Struktur bak kontrol sedimentasi

\section{KESIMPULAN DAN SARAN}

\subsection{Kesimpulan}

Dari hasil penelitian disimpulkan halhal berikut ini.

1. Dimensi saluran awalnya diperkirakan dapat menampung besarnya debit aliran yang terjadi, namun seiring berkembangnya pembangunan perumahan sehingga menambah beban runoff yang masuk pada saluran bertambah, dan kondisi sedimentasi yang juga bertambah sehingga mengurangi kapasitas dari saluran tersebut.

2. Kondisi saluran drainase yang ada saat ini sebagian besar masih dapat menampung debit rencana aliran yang terjadi, namun masih terdapat pada beberapa titik saluran yang kapasitasnya telah berkurang sehingga tidak dapat lagi menampung debit rencana antara lain adalah pada saluran P3 dimana kapasitas hanya dapat menampung debit aliran sebesar $0,982 \mathrm{~m} 3 / \mathrm{s}$ sedangkan debit rencana aliran adalah $1,160 \mathrm{~m} 3 / \mathrm{s}$ dan pada saluran S8 dengan kapasitas 0,176 $\mathrm{m} 3 / \mathrm{s}$ sedangkan debit rencana 0,778 $\mathrm{m} 3 / \mathrm{s}$.

3. Penanganan banjir terhadaap sistem saluran drainase akibat tidak mampu saluran dalam menampung debit adalah dengan merubah dimensi yang telah ada terkhusus pada daluran P3 dan saluran S8 


\section{DynamicSainT}

Jilid. IV No. 2., Oktober 2019

dimana masing-masing harus merubah ketinggian saluran menjadi 1,181 meter dan 1,765 meter ditambah dengan pembuatan bak kontrol sehingga tidak terjadi penumpukan sedimentasi yang dapat menyebabkan berkurangkan kapasitas saluran dalam menampung debit rencana aliran

\subsection{Saran}

Saran yang diberikan oleh penulis berdasarkan hasil penelitian sebagai berikut ini.

1. Perlu dilakukan penerapan sistem konservasi dalam mengalirkan air hujan agar dapat masuk kedalam tanah sehingga dapat mengurangi beban dari kapasitas saluran yang telah ada.

2. Evaluasi pada saluran saluran yang ada perlu dilakukan untuk melihat perubahan kondisi saluran seperti pendangkalan pada saluran maupun semakin banyaknya lahan terbangun yang dapat memperkecil kapasitas saluran dengan cara membuat konstruksi bak kontrol sedimentasi.

3. Perlu dilakukan kajian lebih lanjut tentang analisis terhadap alternatif kostruksi dalam menjaga kapasitas saluran.
4. Kodoatie, J.R. dan Sugiyanto, 2002, Banjir, Beberapa Masalah dan Metode Pengendaliannya dalam Perspektif Lingkungan. Pustaka Pelajar, Yogyakarta.

5. Hasmar Halim, 2002, Drainase Perkotaan, UII Press, Yogyakarta. Horton, R. E., 1933, The Role of Infiltration in the Hydrologic Cycle, Geophy, Union.

6. Sunjoto, 2016, Teknik Drainase Pro-Air dan Konservasi Berkelanjutan, Lecture Note, Yogyakarta.

7. Suripin, 2004, Pengembangan Sistem Drainase yang Berkelanjutan, Andi Offset, Yogyakarta.

8. Triatmojo, B., 2008, Hidrologi Terapan, Beta Offset, Yogyakarta.

\section{DAFTAR PUSTAKA}

1. Agus Maryono, 2005, Menangani Banjir, Kekeringan dan Lingkungan, Gadjah Mada University Press, Yogyakarta.

2. Chay Asdak, 2004, Hidrologi dan Pengelolaan Daerah Aliran Sungai, Gadjah Mada University Press, Yogyakarta.

3. Chow, V.T., Maidment, D.R., and Mays, L.W., 1988, Applied Hydrology, McGraw Hill, Inc., New York. 